\title{
La stratégie auctoriale de Thomas Kilroy dans l'écriture de The Secret Fall of Constance Wilde
}

\section{Thierry Dubost}

\section{(2) OpenEdition}

1 Journals

\section{Édition électronique}

URL : https://journals.openedition.org/etudesirlandaises/10177

DOI : 10.4000/etudesirlandaises. 10177

ISSN : 2259-8863

\section{Éditeur}

Presses universitaires de Caen

\section{Édition imprimée}

Date de publication : 31 décembre 2020

Pagination : $21-34$

ISBN : 978-2-84133-996-9

ISSN : 0183-973X

\section{Référence électronique}

Thierry Dubost, «La stratégie auctoriale de Thomas Kilroy dans l'écriture de The Secret Fall of Constance Wilde», Études irlandaises [En ligne], 45-2 | 2020, mis en ligne le 31 décembre 2020, consulté le 15 novembre 2022. URL : http://journals.openedition.org/etudesirlandaises/10177 ; DOI : https:// doi.org/10.4000/etudesirlandaises. 10177

\section{(c) (i) (2) (2)}

Creative Commons - Attribution - Pas d'Utilisation Commerciale - Partage dans les Mêmes Conditions 4.0 International - CC BY-NC-SA 4.0

https://creativecommons.org/licenses/by-nc-sa/4.0/ 


\title{
La stratégie auctoriale de Thomas Kilroy dans l'écriture de The Secret Fall of Constance Wilde
}

Résumé: The Secret Fall of Constance Wilde, dont la première se déroula à l'Abbey Theatre en 1997, trouve son origine dans une commande du théâtre national visant à célébrer le centenaire de la sortie de prison d'Oscar Wilde. Cette œuvre singulière (Thomas Kilroy s'inspira du Bunraku) invite à revenir sur sa composition. Sans chercher à établir par le détail une archéologie de la création, le processus créatif mis en œuvre initie un questionnement sur la place de Kilroy en tant qu'auteur et son statut au sein de processus culturels, politiques et esthétiques dans les années 1990 en Irlande.

Mots clés: The Secret Fall of Constance Wilde, Thomas Kilroy, Michel Foucault, auteur, processus créatif, théâtre, Abbey Theatre, Bunraku, James Joyce, Thornton Wilder.

\begin{abstract}
The Secret Fall of Constance Wilde premiered at the Abbey Theatre in 1997. It was initially commissioned by the Abbey to help mark the centenary of Wilde's release from prison. This very original dramatic work (Kilroy borrowed elements from Japanese Bunraku) calls for an investigation of the writing process. Without attempting to provide a detailed archeology of Kilroy's creative process, this paper questions his status as a writer, as part of the cultural, political and aesthetic zeitgeist of 1990s Ireland.
\end{abstract}

Keywords: The Secret Fall of Constance Wilde, Thomas Kilroy, Michel Foucault, author, creative process, Irish Theatre, Abbey Theatre, Bunraku, James Joyce, Thornton Wilder.

Dans une préface non publiée consacrée à Finnegans Wake, Thornton Wilder (romancier, dramaturge et intellectuel états-unien), dont la carrière littéraire présente de nombreux points communs avec celle Thomas Kilroy, écrit:

To those who love literature and who follow it closely as a tradition and a craft, it presents itself in the image of a torch race, rather than as a jealous and airless patent office. I hope that in turn others will find occasion to acknowledge an indebtedness to $\mathrm{me}^{1}$.

Après avoir consacré plusieurs années à l'étude de Finnegans Wake ${ }^{2}$ et fait l'objet d'une campagne de diffamation pour plagiat, suite à la publication de The Skin of

1. Thornton Wilder, «Journal 1948-61 », référence 742, 2 juin 1957 (Thornton Niven Wilder Collection, Yale Collection of American Literature, Beinecke Rare Book and Manuscript Library, Yale University).

2. L'intérêt de Wilder pour Joyce n'eut rien d'une passade. Parmi de nombreux autres éléments, sa correspondance exclusivement consacrée à Finnegans Wake (750 pages) en témoigne: A Tour of the Darkling Plain: The Finnegans Wake Letters of Thornton Wilder and Adaline Glasheen, Edward M. Burns, Joshua A. Gaylord (éd.), Dublin, University College Dublin Press, 2001. Pour prolonger les réflexions sur Finnegans Wake, voir notamment Donald Haberman, «Comparisons between 
Our Teeth ${ }^{3}$, pour cause de proximité trop grande avec le roman précité, Wilder revient sur l'influence de Joyce sur ses écrits. Elle ne se limite pas à The Skin of Our Teeth, pièce très originale dans laquelle il avait, entre autres, cité le maître irlandais, d'où l'accusation d'un de ses détracteurs, selon qui cette œuvre n'était pas "an entirely original creation, but an Americanized recreation, thinly disguised, of James Joyce's Finnegans Wake» ${ }^{4}$. À l'époque, les attaques contre Wilder furent retentissantes, virulentes, mais limitées en nombre. En effet, considérer que Finnegans Wake pouvait se réduire à une pièce en trois actes parut pour le moins grotesque à beaucoup de critiques. À ce propos, Wilder dessina lui-même les limites des influences joyciennes, démontrant ainsi l'inanité du discours des deux universitaires qui l'avaient attaqué:

The four fundamental aspects of Finnegans Wake were not to my purpose and are not present in my play. Joyce's novel is primarily a study of Original Sin, and the role it plays in the life of the conscience. Its recurrent motto is St. Augustine's $\mathrm{O}$ felix culpa. Nor could I use its secondary subject, the illustration of Vico's theory of the cyclic seasonal repetitions of human culture. Nor could I find any place for its primary literary intention, the extraordinary means Joyce found for representing the thoughts of the mind while asleep, the famous "night-language". Nor could I employ his secondary literary intention, the technical tour-de-force whereby through puns and slips of the tongue he was able to represent several layers of mental activity going on at the same time and often contradictory to one another. If I had been able to transfer to the stage several or any one of these four basic aspects of the book, wherein its greatness lies, I would have done it and would have gladly published the obligation at every step of the way ${ }^{5}$.

Loin de nier l'influence de Joyce, Wilder en trace les contours pour The Skin of Our Teeth. Sa synthèse met en avant des différences fondamentales, manifestes, qui démontrent que, si Finnegans Wake a partiellement nourri son écriture, il s'agit davantage d'un écho positif que d'une pâle copie. Conformément au point de vue exprimé dans sa préface, l'auteur états-unien indique que la littérature ne saurait être confinée dans quelque «airless patent office», au contraire. Selon lui, les créations

Finnegans Wake and The Skin of Our Teeth have been Exaggerated», in Readings on Thornton Wilder, Katie De Koster (dir.), San Diego, Greenhaven Press, 1998, p. 145-154. Il convient de noter que Joyce ne constituait pas l'unique référence littéraire de Wilder, comme le souligna Malcolm Cowley: "Most of his infatuations have been for classical authors, including Sophocles, Catullus, Virgin, Mme de Sévigné, and La Bruyère, as well as the severely classical Noh drama of Japan, though he has also taken lessons from Proust and Joyce» (Malcolm Cowley, "The Man Who Abolished Time», in Critical Essays on Thornton Wilder, Martin Blank (dir.), New York, G. K. Hall \& Co., 1996, p. 34).

3. Cette pièce lui valut néanmoins un prix Pulitzer en 1942. Si l'on cherchait un autre écho assumé, la fin de The Eighth Day en fournirait un exemple. Le roman, qui fait écho à la conclusion de Finnegans Wake, se termine ainsi: "Some find strength in the conviction that there is nothing to see. Some...» (Thornton Wilder, The Eighth Day, Londres, Penguin, 1968, p. 396).

4. Joseph Campbell, Henry Morton Robinson, "Comparing Finnegans Wake with The Skin of Our Teeth», in Readings on Thornton Wilder, p. 136.

5. Thornton Wilder, cité dans Sidney Feshbach, "Deeply Indebted: On Thornton Wilder's Interest in James Joyce”, James Joyce Quarterly, vol. 31, n 4, 1994, p. 509. 
passées invitent à poursuivre les investigations esthétiques des prédécesseurs et à relever les défis qu'ils s'étaient lancés. Ainsi, Wilder inscrit la littérature au sein d'une tradition et met l'accent sur le métier («craft»). L'évocation de ces deux aspects contient en filigrane une interrogation sur la création, ses continuités et ses origines. Avec sa modestie habituelle, sans s'attacher précisément à la figure du démiurge, Wilder questionne indirectement la place de l'auteur dans la conception de l'œuvre et le cantonne dans un rôle de passeur ${ }^{6}$. Son regard optimiste quant au passage de témoin entre générations d'écrivains tranche nettement avec le contenu d'un article programmatique intitulé «Groundwork for an Irish Theatre» que Kilroy publia dans Studies en 1959. Dans cette contribution remarquée, le jeune universitaire évoqua la force tétanisante des créateurs d'antan pour ceux qui envisageaient d'écrire pour la scène, mais ouvrit également de nouvelles perspectives pour le théâtre irlandais: "Too often the view from our modern Irish windows is cluttered-up with distracting monuments to the dead and glorious past of politics and art ${ }^{7}$.

Contrairement à Wilder, Kilroy exprimait son inquiétude par rapport à une prestigieuse tradition littéraire irlandaise devenue étouffante. Selon lui, les œuvres du passé ainsi que leurs créateurs constituaient un gigantesque monument aux morts dont l'ombre portée nuisait au renouvellement créatif des aspirants écrivains. Selon Wilder, outre-Atlantique, le passage de témoin marquait une continuité, tout en confirmant la possibilité de libre entreprise littéraire, contrairement à l'Irlande, où les émancipations créatrices restaient timides. Dans Studies, Kilroy s'insurgea donc contre un culte mortifère et, ce faisant, porta un discours libérateur qui, sans avoir une valeur performative, traça néanmoins la voie du renouvellement théâtral irlandais. Son questionnement initia un débat public portant notamment sur le poids des traditions, ainsi que sur les cadres esthétiques à l'intérieur desquels les dramaturges étaient confinés.

L'écriture, puis la programmation de The Secret Fall of Constance Wilde ${ }^{8}$, à l'Abbey Theatre en 1997, témoigne d'une émancipation auctoriale revendiquée puis obtenue. En effet, rompant avec les attentes, à partir d'une biographie partiellement imaginée, Kilroy mit l'épouse d'Oscar Wilde sur le devant de la scène et doubla ce choix thématique par une esthétique atypique, empruntée au Bunraku. Ce faisant, le dramaturge irlandais s'inscrivait dans les pas de son illustre prédécesseur, W. B. Yeats, lequel avait ponctuellement rompu avec les esthétiques occidentales en s'inspirant

6. Dans un sens légèrement voisin de celui de Baudrillard, qui s'est exprimé sur le sujet: «Car les mots sont porteurs, générateurs d'idées, plus encore, peut-être, que l'inverse. Opérateurs de charme, opérateurs magiques, non seulement ils transmettent ces idées et ces choses, mais eux-mêmes se métaphorisent, se métabolisent les uns dans les autres, selon une sorte d'évolution en spirale. C'est ainsi qu'ils sont passeurs d'idées" (Jean Baudrillard, Mots de passe, Paris, Fayard, 2000, p. 9). Dans le cas de Wilder, plus que passeurs d'idées, les mots sont peut-être avant tout des passeurs de formes.

7. Thomas Kilroy, "Groundwork for an Irish Theatre», Studies: An Irish Quaterly Review, vol. 48, no 190, 1959, p. 192.

8. Thomas Kilroy, The Secret Fall of Constance Wilde, Loughcrew, The Gallery Press, 1997; édition française: Thomas Kilroy, La chute secrète de Constance Wilde, Thierry Dubost (trad.), Caen, Presses universitaires de Caen, 2016. 
du Noh. Outre ses connaissances livresques, un séjour de trois mois à Kyoto avait permis à Kilroy de découvrir les différentes formes de théâtre classique japonais ${ }^{9}$. Son basculement dans un cadre esthétique allochtone fut d'autant moins surprenant que l'expérimentation occupe une place centrale dans son écriture théâtrale. Cette inspiration exotique traduisait notamment une volonté d'afficher une théâtralité de l'artifice - en opposition aux pratiques usuelles dans le théâtre irlandais de l'époque. Par ailleurs, la mise en relief du jeu, des codes, des rituels, ainsi que la présentation de l'être comme une série de personnages insaisissables, faisaient écho à ce que Kilroy perçoit comme un trait fondamental de l'esthétique de Wilde: la mise à distance.

Dans la mesure où Kilroy est l'auteur d'adaptations d'œuvres étrangères, de Tchekhov, Ibsen, Pirandello ou Wedekind, son passage par une esthétique orientale pourrait sembler équivaloir aux réécritures susmentionnées. En effet, la volonté d'élargir l'horizon d'attente du spectateur irlandais constitue un point commun entre ses adaptations et la commande de l'Abbey Theatre, mais la démarche d'écriture s'avère fort différente. De Tchekhov à Wedekind, Kilroy s'est approprié des œuvres existantes; il les a adaptées afin de sortir d'un prisme de lecture britannique, en montrant comment elles entraient en résonance avec la société irlandaise. The Secret Fall of Constance Wilde traduit un tout autre fonctionnement. Il s'agit cette fois d'une création proposée au dramaturge, qui y introduit un personnage souvent oublié dans les infortunes wildiennes - Constance - en s'affranchissant de toute fidélité biographique: "She is quite distinctly an invention on my part» ${ }^{10}$. Le risque d'asservissement historique se doublait, dans l'acte d'écriture, de celui d'une imitation d'un style wildien, lequel surgit parfois dans la pièce, et qui aurait pu donner un ton futile à cette œuvre profonde. Le détour stylistique oriental, une importation plus qu'une adaptation, permettait paradoxalement à Kilroy d'ouvrir des nouvelles voies créatrices via des contraintes formelles atypiques.

Trente-sept années après sa revendication d'indépendance, la cohérence intellectuelle du dramaturge est patente, mais il convient peut-être de revenir sur un acte créateur plus complexe qu'il n'y paraît, car il dépasse le cadre d'une écriture solitaire et interroge de facto la place et le statut de l'auteur dans un environnement social donné. Sans prétendre constituer une archéologie de la création de The Secret Fall of Constance Wilde, grâce aux archives désormais disponibles dans le fonds Kilroy à l'université de Galway ${ }^{11}$, il reste qu'une prise en compte d'aspects institutionnels, politiques et dramaturgiques - liés à la composition de l'œuvre - devrait permettre

9. Kilroy le résume ainsi: «I had very little difficulty responding to Bunraku and Kabuki and at a lesser extent, the Noh plays. So that, for example, the conception of puppetry in my most recent play, started out as a kind of use of Bunraku puppeteers. We lost those as the thing went on, and they finally became something else, but the notion of figures, mute figures on a stage manipulating things appeal to me a greatly in relation to the Oscar Wilde material for a variety of reasons" (Thierry Dubost, "An Interview with Thomas Kilroy», in The Plays of Thomas Kilroy: A Critical Study, Jefferson, McFarland, 2007, p. 129).

10. Thierry Dubost, "An Interview with Thomas Kilroy», p. 133.

11. "The Papers of Thomas Kilroy», James Hardiman Library Archives, National University of Ireland, Galway. 
de l'évaluer sous des angles nouveaux. Ces éléments permettront de comprendre comment, dans le cadre de cette création singulière, Kilroy s'est situé dans le paysage dramatique irlandais et a contribué à définir une figure de l'auteur. En l'occurrence, interroger les rapports à la tradition et à la création conduira moins à dresser le constat d'une orthodoxie créatrice vis-à-vis d'attendus sociétaux qu'à mesurer comment l'écriture de The Secret Fall of Constance Wilde trace le portrait d'un dramaturge dans son action créatrice.

Avant de s'attacher à la manière dont The Secret Fall of Constance Wilde a élargi le spectre du théâtre irlandais de l'époque, un retour contextuel paraît nécessaire. Loin de relever de l'évidence, au moins sur le plan de la réception publique, la réintroduction d'Oscar Wilde à l'Abbey Theatre constituait un élément marquant et fut dépeinte comme tel par la critique:

In 1996, Mason did something that no Abbey artistic director had done before: he produced Oscar Wilde's A Woman of No Importance on the theatre's main stage. Wilde's Importance of Being Earnest followed in 1997. He also directed Thomas Kilroy's The Secret Fall of Constance Wilde (1997), a play that makes explicit the relationship between Wilde's theatre and his sexuality ${ }^{12}$.

Sans s'apparenter à une révolution copernicienne, il reste que la programmation de A Woman of No Importance sur la scène principale du théâtre national - une première, comme le souligne Lonergan - constituait un choix signifiant ${ }^{13}$. La mise en avant de cette pièce inaboutie contribuait à redéfinir Wilde comme dramaturge dont l'œuvre ne se limitait pas à The Importance of Being Earnest. Écrite deux ans avant la célébrissime comédie wildienne, A Woman of No Importance plaçait l'identité, la filiation, mais aussi la manière dont la société maltraitait une femme qui avait fauté, au centre d'un questionnement contemporain qui abordait différemment les enjeux initialement traités par Wilde. En effet, par un renversement conclusif, il bousculait les perspectives, démontrant que la personne sans importance était en vérité un homme, Lord Illingworth. Ce faisant, il questionnait la pertinence des constructions sociales et ceux qui les validaient, en l'occurrence, les spectateurs.

Sur le plan politique que constitue toute programmation d'un théâtre national, monter A Woman of No Importance constituait un geste fort. Grâce à cette démarche, Patrick Mason interrogeait le répertoire de l'Abbey Theatre tel que ses prédécesseurs l'avaient conçu ${ }^{14}$. Outre un désir de redéfinir la place de Wilde au

12. Patrick Lonergan, Theatre and Globalization: Irish Drama in the Celtic Tiger Era, Basingstoke, Palgrave Macmillan, 2009, p. 146.

13. Outre la production de ses œuvres, Oscar Wilde avait bénéficié d'une présence notable à l'Abbey Theatre en 1989, avec la production de Saint Oscar de Terry Eagleton. Initialement produite par la Field Day Theatre Company, la pièce fut reprise à l'Abbey Theatre en novembre 1989.

14. Patrick Mason a effectué sa première mise en scène en 1977, à l'Abbey Theatre (Dublin), qu'il a dirigé de 1993 à 1999. Il a collaboré avec de nombreux dramaturges irlandais tels que Brian Friel, Hugh Leonard, Tom Murphy, Tom Kilroy, Tom MacIntyre, ainsi que Frank McGuinness. Patrick Mason a également exercé au Gate Theatre (Dublin), théâtre dans lequel il a, depuis 1983, mis en scène des œuvres de dramaturges anglo-irlandais, Farquhar, Sheridan, Wilde et Shaw. Il a 
théâtre national (Mason avait déjà monté cette pièce en 1983 au Gate Theatre), sa démarche invitait, via une lecture féministe latente, à repenser la place de la femme dans la société irlandaise. En 1996, Wilde était depuis longtemps sorti du purgatoire; en sus des motifs esthétiques et politiques, sa présence s'expliquait également pour des raisons financières, ignorées du public et des critiques ${ }^{15}$.

Soucieux d'actualiser le regard porté sur Wilde, Mason fit appel à Kilroy pour écrire une œuvre contemporaine: "In 1996 I was commissioned by the Abbey Theatre to write a play with a Wildean theme to help mark the centenary in 1998 of Wilde's release from prison $[. ..]{ }^{16}$.

Célébrer la levée d'écrou au théâtre national constituait un acte politique. Pardelà le salut rétrospectif à un créateur martyrisé, hommage était rendu à un homme que la société avait condamné, pour des motifs implicitement validés en Irlande, via un désengagement qui s'apparentait à une censure ${ }^{17}$. Il s'agissait moins de lever le masque sur un passé - que nul n'ignorait désormais - que d’interroger la société irlandaise sur son positionnement face à une homosexualité désormais légale ${ }^{18}$.

A priori banale, la référence à une commande, "commissioned», constitue un point saillant dans les dires de Kilroy. En effet, loin des présupposés reposant sur une génération spontanée du génie créateur, la chiquenaude inchoative pour ce travail d'écriture revenait à l'État, en la personne du directeur du théâtre national. Cette commande publique, qui n'avait rien d'exceptionnel, traduisait un engagement régalien dans le domaine de la création. Dans ses dimensions financières et programmatiques, outre que cette implication éclaire les conditions qui ont rendu possible l'écriture de The Secret Fall of Constance Wilde, le mode opératoire définissait les contours d'un statut auctorial. Dans le cadre d'un projet subventionné, quel que soit le domaine artistique considéré, le rapport qui s'établit entre un commanditaire institutionnel et un artiste figure au nombre des traditions liées à la création. Une commande implique un double volet: d'une part, un projet, dont les attentes sont consignées par écrit afin que l'artiste dispose d'un cadre d'intervention; d'autre part, toute proposition de collaboration implique

également signé la mise en scène de nombreux opéras. Outre l'Irlande, ses productions ont été montées en Angleterre, en France, en Russie, en Australie et aux États-Unis.

15. "Producing it at the Abbey made perfect sense artistically and, most importantly for me at the time, commercially. The theatre was still struggling financially and the Wilde plays were extremely important to restoring the finances - which they did» (Patrick Mason, conversation privée par courriel, 9 septembre 2017).

16. Thomas Kilroy, "The Wildean Triangle», in What Revels Are in Hand? Assessments of Contemporary Drama in English in Honour of Wolfgang Lippke, Bernhard Reitz, Heiko Stahl (dir.), Trier, Wissenschaftlicher Verlag Trier (Contemporary Drama in English; 8), 2001, p. 47.

17. «After his trial in 1895, touring productions of his plays faded away, and it was to be thirty years before his plays became part of the Irish repertoire " (Chris Morash, A History of Irish Theatre, Cambridge, Cambridge University Press, 2002, p. 107).

18. "Although Constance is shown to be unusual in her understanding of Oscar's sexuality, and courageous and angry in her hate of hypocrisy, the play contextualizes homosexuality in suffering, trauma and disgrace» (Margaret Llewellyn-Jones, Contemporary Irish Drama and Cultural Identity, Portland, Intellect, 2002, p. 115). 
des attentes quant à la création envisagée, en fonction des talents que l'on prête au futur intervenant.

Kilroy fut donc choisi pour ce travail et, d'une manière sans doute moins anecdotique qu'il n'y paraît, cette commande fut moralement salutaire. En effet, suite à la réception critique désastreuse de The Madame MacAdam Travelling Theatre, le dramaturge avait annoncé qu'il mettait un terme à sa carrière ${ }^{19}$, mais la proposition de Mason lui remit la plume à l'encrier.

Par-delà le metteur en scène, cette collaboration impliquait toute une équipe; à mesure qu'ils recevaient les esquisses, les lecteurs servaient de chambre d'écho:

Is Constance on stage because of what she might illuminate for us about her brilliant husband? Is she a new mirror for Wilde? Or is there no question but, as the title says, the play is Constance's ${ }^{20}$ ?

En analysant les comptes rendus de lecture, l'impression qui se dégage est celle d'un créateur en liberté surveillée, avec des retours néanmoins globalement positifs. Aux échanges épistolaires, il convient d'ajouter un dialogue continu entre le futur metteur en scène et l'auteur. Cet examen extérieur, conduit à mesure de l'élaboration de la pièce, peut sembler d'autant plus surprenant sur le plan de la maîtrise de la création que la finalisation du texte s'opère souvent (c'est le cas pour Kilroy) lors des répétitions. Cependant, les premiers retours concernaient davantage l'architecture globale de l'œuvre que des aspects précis.

L'accès au processus de création, tel qu'il apparaît dans les archives du fonds Kilroy, conduit à reposer une célèbre question: qu'est-ce qu'un auteur? Cette interrogation, Michel Foucault l'avait retenue comme titre d'un article dans lequel il évoquait le rapport d'appropriation qui lie un créateur à son œuvre:

[...] l'auteur n'est exactement ni le propriétaire ni le responsable de ses textes; il n'en est ni le producteur ni l'inventeur. Quelle est la nature du speech act qui permet de dire qu'il y a œuvre ${ }^{21}$ ?

En ce qui concerne The Secret Fall of Constance Wilde, le premier élément qui «permet de dire qu'il y a œuvre» réside dans sa dénomination. Par un lent processus

19. "Yet after the savage reviews that meted out to his The Madame MacAdam Travelling Theatre in 1991, especially in Dublin, Kilroy said publicly he would not write for the stage again. He has, however, accepted a commission from the Abbey for a play on Wilde, and Wife to Mr Wilde is scheduled for production in 1996" (Christopher Murray, "The State of Play: Irish Theatre in the Nineties", in State of Play: Irish Theatre in the Nineties, Eberhard Bort (dir.), Trier, Wissenschaftlicher Verlag Trier, 1996, p. 13).

20. Judy Friel, $1^{\text {er }}$ décembre 1996, "The Papers of Thomas Kilroy», P103/240/15. Certains retours de lecteurs étaient encourageants: "It is therefore kind of refreshing to read an imaginative work from the same boudoir, so to speak, which is so allusive (verbally and visually) and so witty and aphoristic in its own vein and without the pronunciation of soi-dite [sic] Wildean epigrams except perhaps ironically" (lettre signée Christopher - membre de l'Abbey Theatre à l'époque -, 5 décembre 1995, "The Papers of Thomas Kilroy», P103/240/12).

21. Michel Foucault, "Qu'est-ce qu'un auteur?», in Dits et écrits, 1954-1988, t. I, 1954-1975, Paris, Gallimard, 2001, p. 817. 
de dérivation, lié à l'auteur, le titre de la pièce évolua. La perspective originale, telle que proposée par le metteur en scène, était la suivante: «Let's agree to call the piece "The Untitled Wilde Play" and go for the delivery of a first draft in January 1995»22. Quelques mois plus tard, après des échanges épistolaires et téléphoniques, Mason écrivit: "Thank you for sending Wife to Mr Wilde» ${ }^{23}$. La correspondance entre le metteur en scène et le dramaturge atteste que l'évolution fut progressive, comme le confirme un entretien accordé en 2001:

The more I explored Wilde once again the more interested I became in the story of his wife, Constance. She was like a shadow in the familiar story of his brilliant career as a wit and dramatist, a forgotten presence behind his collapse and imprisonment ${ }^{24}$.

Par un retournement de perspectives - très wildien dans sa dimension paradoxale, puisqu'il relègue le Maître en position seconde - Kilroy s'attacha à la mise en avant d'une figure de l'ombre, balayant d'un revers de plume toute démarche élégiaque uniquement focalisée sur l'écrivain. Il opta, à l'inverse, pour l'écriture scénique d'un drame humain, pensé selon des lignes de force de son esthétique de l'époque, en gardant une certaine distance avec son sujet.

À propos de la conception de The Secret Fall of Constance Wilde, il vaut de noter que la création, qui est une forme de pensée, est marquée par son époque ${ }^{25}$. Sans qualifier la démarche de féministe, il reste que, thématiquement, s'intéresser à une femme dont les infortunes conjugales avaient jusqu'alors été traitées de manière connexe, voire ignorées, signale un phasage du créateur avec son temps. La question soulevée en découvrant le manuscrit, quand une lectrice s'efforçait de préciser la place de Constance (faire-valoir d'un nouveau type ou non), souligne indirectement l'engagement de l'auteur. À cet égard, l'hypothèse finale de la relectrice, «the play is Constance's", met en relief une stratégie d'écriture car, par ce bouleversement inattendu, Kilroy donne voix à un mutisme socialement construit, qu'il condamne implicitement. Sans être frappée du sceau du militantisme, cette approche témoignait d'un engagement souvent passé inaperçu, car Constance se voit finalement octroyer une place centrale, comme victime d'emprisonnements sociaux. En effet, la manière dont le discours politique s'inscrit dans les œuvres de Kilroy diffère des approches en usage lors de la création d'un théâtre national. C'est pourquoi, en évoquant quelques auteurs irlandais majeurs, au nombre desquels figure Kilroy, Declan Kiberd écrit:

This is not to say that the authors named all endorsed his [Beckett's] apparent indifference to society: but it is to suggest that his elevation of the estranged artist as a model had immense implications. [...] The decade after the foundation of Aosdana saw hunger strikes in the north, vast unemployment in the south, the wrongful imprisonment of suspects

22. "The Papers of Thomas Kilroy», 21 février 1994, P103/240/8.

23. "The Papers of Thomas Kilroy», 5 juillet 1995, P103/240/9.

24. Thomas Kilroy, "The Wildean Triangle», p. 50.

25. «La pensée a également une histoire; la pensée est un fait historique, même si elle a bien d'autres dimensions que celle-là " (Michel Foucault, «Le souci de la vérité», in Dits et écrits, 1954-1988, t. II, 1976-1988, Paris, Gallimard, 2001, p. 1488). 
in British jails, and the divisive divorce and abortion referenda, yet these events passed without finding their laureate. It would be difficult to imagine a Yeats or an O'Casey failing to use such material ${ }^{26}$.

À l'évidence, aucun des sujets mentionnés par Kiberd ne compte au nombre de ceux retenus par Kilroy. Cependant, il convient de garder en mémoire que, sans emprunter la voie d'un prosélytisme didactique, le dramaturge a toujours articulé son écriture avec la société, suscitant subtilement l'interrogation quant à la manière dont les Irlandais se définissaient en tant que communauté. Ainsi, avec The Death and Resurrection of $\mathrm{Mr}$ Roche, il fut le premier dramaturge irlandais à donner un rôle central à un homosexuel ${ }^{27}$. Dans un autre champ de la pensée, The O'Neill et Double Cross interrogent l'histoire comme construction sociale et l'identité comme fiction, en prenant en compte des conflits identitaires majeurs, un sectarisme rampant et délétère ${ }^{28}$. Sans dresser la liste de ses engagements, il reste que, dans The Secret Fall of Constance Wilde, la place octroyée à Constance donne une dimension politique à

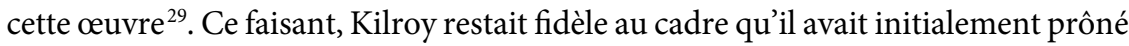
pour les écrits dramatiques ${ }^{30}$. Toute approche militante est exclue, mais dans cette pièce formellement atypique, Constance devient la figure de proue de souffrances ordinaires qui trouvaient de multiples échos auprès d'un public irlandais de la fin du $\mathrm{XX}^{\mathrm{e}}$ siècle $^{31}$. Par-delà le naufrage d'un couple, la mise en relief d'une victime

26. Declan Kiberd, Inventing Ireland: The Literature of the Modern Nation, Londres, Ramdom House, 1996, p. 584.

27. Il ne fut pas le seul à aborder l'homosexualité sur la scène irlandaise. Il avait été précédé par Brendan Behan, avec The Quare Fellow en 1954, ainsi que par Brian Friel, avec The Gentle Island en 1971. Pour rappel, en Irlande, la décriminalisation de l'homosexualité fut votée en 1993.

28. "At the time The O'Neill was staged in 1969 Ireland was about to be challenged once again by the dream of national unity, while on the other side of the equation Europe beckoned towards wider horizons as it had in O'Neill's day. [...] Kilroy's play raised contemporary issues in a stimulating and prophetic way» (Christopher Murray, Twentieth-Century Irish Drama: Mirror Up to a Nation, Manchester, Manchester University Press, 1997, p. 184).

29. Ce que certains critiques ont souligné: «Kilroy has undertaken in his play consciously to redress that balance, to rescue Constance Wilde and the two boys from oblivion by dramatizing the private tragedy which accompanied the spectacular public fall of Oscar Wilde, to place the passionate and probing intelligence of his Constance at the dramatic centre while Oscar for once is sidelined " (Anthony Roche, Contemporary Irish Drama, $2^{e}$ éd., Dublin, Palgrave Macmillan, 2009, p. 150-151). Il convient de noter l'importance de cet aspect, qui réapparait sous des formes variées entre le tapuscrit et la version finale: "Constance How you turned away from me! Being a woman I blamed myself, of course. We always do, you know» ("The Papers of Thomas Kilroy», P103/237); printed text: "Constance How you turned away from me with that stylish disgust of yours! I blamed myself, of course, lying there in the darkness. Women always do" (Thomas Kilroy, The Secret Fall of Constance Wilde, p. 14).

30. "The serious dramatist should fulfill the role of commentator on current values, practicing espionage for everyman" (Thomas Kilroy, "Groundwork for an Irish Theatre», p. 195).

31. José Lanters écrit: "Constance's quest to face herself as she "really" is, however, is complicated by the play's Brechtian emphasis on performance, through its use of puppets, masks, costumes changes and choreographed movement» (José Lanters, The Theatre of Thomas Kilroy: No Absolutes, Cork, Cork University Press, 2018, p. 131). On pourrait arguer, à l'inverse, que l'artifice de la représentation s'avère utile, même essentiel: "[...] Thomas Kilroy, anxious to stage some of the subterfuges of theatrical expression, lays special emphasis on the artificiality of performance. In this dramatic work, he explores the question of the masking and unmasking of the inner self as an invisible oppression. 
qui souhaite dévoiler les violences sexuelles subies dans son enfance redéfinit son statut de femme, fait d'elle une Antigone contemporaine, mais opposée à la figure classique, telle que la caractérise George Steiner:

En prenant sur elle la culpabilité inévitable qui s'attache à l'action, en opposant le féminin ontologique au masculin politique, Antigone s'élève plus haut qu'CEdipe: son «crime» est commis en toute conscience. C'est un acte de maîtrise de soi avant d'être l'acceptation du destin ${ }^{32}$.

Sans ériger Constance en modèle, Kilroy réfute un féminin «ontologique » qui relève, en réalité, des constructions sociales. Il place Constance sur le terrain de la parole, et sa sortie du mutisme s'apparente à une négation du destin. Elle revendique son droit à l'expression, d'où un basculement politique dû̀ ù retournement inattendu. En effet, Kilroy s'attache à Wilde, non pour revenir sur sa condition d'homosexuel scandaleusement condamné, mais pour questionner la façon dont la société restreint ou empêche l'expression des différences. À l'inverse d'Oscar, qui se réfugie dans une double fuite, langagière ou spatiale, son épouse affiche sa détresse, sans détours, ce qui donne vie à un personnage inattendu:

CONSTANCE: No, Oscar, not that anymore. Never again will I be invented as the good woman. Never! Constance who never screamed aloud at what was being done to her, the good woman who ran with her children, away from the horror, the filth; the good wife who kept him in money throughout even while he betrayed her. No. I want myself restored to me now. As I really am! Even if it is to be at the very end ${ }^{33}$.

Cet échange rappelle la situation de Lady Windermere et Mrs. Arbuthnot, que Wilde avait mises en scène dans Lady Windermere's Fan et $A$ Woman of No Importance, mais Kilroy opte pour une autre stratégie d'écriture, en extrayant son personnage de l'emprisonnement silencieux dans lequel toute fallen woman était socialement confinée. Il s'affranchit manifestement des fidélités historiques attendues et, ce faisant, questionne la doxa, mettant en cause un pseudo statut ontologique de la femme, selon lequel elle serait vouée au silence.

Characters, puppets and language are among the devices the playwright uses to fuel his reflection, and in The Secret Fall of Constance Wilde, he attempts to probe into the very essence of a person's being» (Thierry Dubost, The Plays of Thomas Kilroy..., p. 69).

32. George Steiner, Les Antigones, Philippe Blanchard (trad.), Paris, Gallimard, 1986, p. 39. Steiner souligne à juste titre l'importance de cette figure féminine, et son importance pour Yeats se retrouve en écho chez Kilroy: "À la charnière du XIX et du XX ${ }^{\mathrm{e}}$ siècle, c'est vers Antigone que se tourne Yeats parce que lui-même, ses pièces de théâtre et sa vie publique sont en proie à cette dialectique mortelle [l'intimité et de l'engagement, du domestique et du public]» (ibid., p. 12-13). Il ajoute: «L'Antigone de Kierkegaard [...] L'Angst a rempli à ras bord sa coupe de douleur. Mais "rien n'ennoblit autant un être humain que de conserver un secret", même si c'est un secret douloureux à mourir» (ibid., p. 66). Le propos de Steiner met en relief la particularité de «l'Antigone» kilroyenne, qui rompt le silence et, de ce fait, récuse les attentes sociétales autour d'un mutisme essentiellement féminin.

33. Thomas Kilroy, The Secret Fall of Constance Wilde, p. 13. 
Bien que Constance occupe une place de premier plan, Oscar conserve un rôle majeur dans le drame, même si Kilroy trace de lui un portrait peu flatteur ${ }^{34}$. Refusant la facilité des hagiographies doucereuses, il rejette tout mimétisme biographique, mais emprunte la voix d'Oscar pour définir son projet d'écriture (OSCAR: Everything I write is autobiographical. With the facts changed, of course ${ }^{35}$ ). Grâce à ces mises à distance, il donne une profondeur humaine à son personnage et rend un bel hommage à Wilde, en transformant sa vie en œuvre d'art ${ }^{36}$. Il prend acte de la présence tutélaire du Maître, mais pour mieux s'en affranchir. À l'inverse de Tea and Sex and Shakespeare, où un dramaturge en mal d'inspiration téléphone au Barde, afin qu'il lui souffle une fin acceptable pour sa pièce, Kilroy affirme sa différence dès que les acteurs pénètrent sur le plateau.

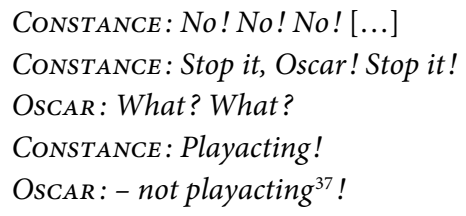

La scène d'ouverture représente une dispute conjugale, mais il semble que l'échange puisse se décoder à plusieurs niveaux. Dès la première réplique, en prélude à sa libération verbale, Constance inscrit la réfutation au cœur de son propos. Elle interpelle Oscar en tant que personnage, car elle cherche à mettre à bas les masques, et son rejet d'une théâtralité intime, telle que pratiquée par son époux, "playacting», renvoie également au déroulement de la scène à laquelle assiste le spectateur. Son comportement rappelle la distanciation brechtienne inaugurale de The O'Neill, la première pièce de Kilroy, dans laquelle le dramaturge mettait l'accent sur la théâtralité et sur l'écriture de l'histoire comme fiction. Dans The Secret Fall of Constance Wilde, le dramaturge opte pour une approche moins tranchée; il place ostensiblement le jeu théâtral au cœur de la représentation, mais se glisse dans les paroles de Constance pour s'adresser à son illustre aîné.

Dès la scène d'ouverture, Kilroy aborde la question de l'écriture dramatique. La complexité créatrice, irréductible à un passage de flambeau tel que l'envisageait

34. Ce que corrobore Graham Price: «However, as Kilroy is almost certainly aware, by appropriating the tools of a prescriptive society, Kilroy's Wilde is making himself a part of that oppressive culture. His appropriation of that society's powers of prescription merely serves to make Wilde into a conformist as opposed to a rebel. Thus, like Joyce and Bracken in Double Cross, the character Wilde in this play exchanges the role of oppressed for that of oppressor" (Graham Price, Oscar Wilde and Contemporary Irish Drama: Learning to Be Oscar's Contemporary, Londres, Palgrave Macmillan, 2018, p. 130).

35. Thomas Kilroy, The Secret Fall of Constance Wilde, p. 25.

36. Le projet d'écriture d'Eagleton, tel qu'il se manifeste dans Saint Oscar, diffère quelque peu de la démarche de Kilroy, car Eagleton s'attache à une réinvention du personnage de Wilde en mettant fortement l'accent sur ses origines irlandaises. Eagleton donne à sa pièce une dimension politique via le discours de son personnage, lequel croque ironiquement la société anglaise et ses pratiques coloniales. Wilde s'attache avec humour à l'hypocrisie des idéologies de l'époque; il questionne les certitudes de ses contemporains, notamment celles concernant la vérité et l'identité.

37. Thomas Kilroy, The Secret Fall of Constance Wilde, p. 11. 
Thornton Wilder, interroge la composition d'une œuvre théâtrale construite autour d'un dialogue établi avec la figure de Wilde. Paradoxalement, dans cet échange entre Oscar (personnage miroir d'un dramaturge) et un auteur, certes invisible, mais qui impose sa marque dès l'origine, le verbe n'occupe qu'une place de second plan.

A dark stage. The attendant figures, mute, emerge out of the darkness: white faceless masks, bowler hats, tight Victorian jackets, chequered pants, white gloves, a cross between Victorian toffs and street theatre performers, stage-hands and puppeteers, dressers, waiters and Figures of Fate.

Out of the darkness four of the attendant figures roll a great white disk, a performance space like a circus ring, into place downstage under a brilliant spot.

At the same time the voice of Constance from the darkness crying: "No! No! No!"

Then two other attendant figures lead Oscar and Constance into the spot, onto the disk, rather like hospital attendants with frail patients ${ }^{38}$.

Par un retour aux sources du théâtre (étymologiquement lieu où l'on regarde), Kilroy pose les fondements de son approche de la scène. L'arrivée d'assistants fantasmagoriques témoigne de sa rupture avec l'esthétique réaliste qui prévalait en Irlande à l'époque. En outre, le recours aux masques, ainsi que les personnages désincarnés, annonçaient l'utilisation future des marionnettes ${ }^{39}$, tandis qu'une gestuelle ritualisée soulignait combien les codes retenus s'écartaient des attentes spectatorielles en vigueur: "With The Secret Fall of Constance Wilde, the whole use of puppets, and as it were, a kind of circle on stage, a white circle on stage, this was there from the very beginning ${ }^{40}$. Au commencement étaient la lumière et les marionnettes... Ce retour sur le processus de création, relaté par l'auteur, permet de mieux saisir la manière dont Kilroy interagit avec Wilde, autour d'un dispositif scénique atypique, qui annonce sa redéfinition de l'écriture dramatique. À mesure que sont évoquées les infortunes du couple, outre la mise en place d'une herméneutique liée à l'élucidation de la chute de Constance, le spectateur relève quelques imitations, des convergences avec les écrits du Maître, en décalage avec une approche théâtrale inhabituelle, très fortement inspirée du Bunraku ${ }^{41}$. Au cœur de l'hommage rendu à Wilde - même si la critique anglaise ne l'a pas perçu comme tel ${ }^{42}$ - l'écriture de Kilroy inscrivait The Secret Fall of Constance Wilde dans une tradition, non pour la subvertir, mais pour signifier que toute biographie

38. Thomas Kilroy, The Secret Fall of Constance Wilde, p. 11.

39. La présence de marionnettes sur la scène de l'Abbey Theatre n'eut rien d'unique, comme en témoigne l'adaptation de Ulysses de Joyce par Dermot Bolger en 2017.

40. Thierry Dubost, «An Interview with Thomas Kilroy», p. 138.

41. Dès l'origine. Voir «The Papers of Thomas Kilroy», P103/238/2: «Six attendants in black Bunrakustyle robes, with puppets». Dans la version publiée, la description des dramatis personae est rédigée comme suit: «Six attendant puppeteers, white, faceless masks, bowler hats, Victorian jackets and pants, white gloves, clappers» (Thomas Kilroy, The Secret Fall of Constance Wilde, p. 7).

42. "I think it's a very important play. We had a success with it in Dublin, and also at the Melbourne Arts Festival in Australia. But it proved unexpectedly controversial in London where it was seen as an attack on Wilde - and therefore homophobic!» (Patrick Mason, conversation privée par courriel, 9 septembre 2017). 
théâtrale de son prédécesseur impliquait de penser la tradition sous forme de ruptures, tout en restant fidèle à l'écriture wildienne, via une esthétique frappée du sceau de l'originalité.

La rupture esthétique, qui emprunte des chemins théâtraux étrangers à l'Irlande, aboutit à une approche distanciée de l'humain, apparemment antinomique avec ce qui émane de la présence d'un acteur dans un drame réaliste. Cependant, par un retournement paradoxal, les affrontements verbaux, les échanges ou les confidences octroient une épaisseur aux personnages, qui n'en deviennent que plus émouvants lorsqu'ils perdent la maîtrise de leur vie. Refusant le pathos, Kilroy parvient néanmoins à donner une intensité émotionnelle aux actions représentées ${ }^{43}$. En effet, le Bunraku recompose les situations classiques; ainsi, lorsque Constance ou Oscar sont conduits sur l'espace blanc, leur prise en charge illustre leur perte d'autonomie car, malgré leur vitalité discursive, le spectateur entrevoit le spectre de déchirures fatales.

Outre la mise en place d'un dispositif scénique très élaboré, la stratégie auctoriale transparaît dans la structure même de l'œuvre. Sur ce plan, elle répond de façons multiples à la commande de l'Abbey Theatre, qui visait à célébrer la sortie de prison d'Oscar. La pièce renvoie à la manière dont se construit une identité sociale et au châtiment d'un homme qui défiait les lois en vigueur à l'époque victorienne ${ }^{44}$. En réponse à la multiplicité des regards accusateurs, dans une lettre testamentaire écrite à ses enfants, Constance propose un autre regard:

[...] your father is a great man. He had this terrible, strange vision. He sacrificed everything to reach out to that vision - that was very brave, wasn't it? You see what he did was to try to release the soul from his body, even when his body was still alive $-{ }^{45}$

Cyril et Vyvyan sont destinataires d'un écrit qui dresse le portrait d'un homme aux prises avec des tourments hors du commun. Par-delà le père, Oscar Wilde transparaît dans cette description d'un être révélé dans ses réalités intimes. Sans chercher à réhabiliter un artiste, qui n'avait plus à l'être en Irlande à la fin du $\mathrm{XX}^{\mathrm{e}}$ siècle, Kilroy donne à son épouse - voix solitaire désormais incontestée - un pouvoir

43. À ce propos, Bertha Csilla souligne la richesse des résonances qui opèrent dans la pièce: «The drama of Oscar and Constance Wilde, while immediately distanced from the audience in the manner of the epic theatre, allowing and helping the audience to reflect on the issues, does not alienate them from feeling for the characters' suffering and struggles. Reflecting on the protagonists' problems obviously inspires self-reflection on the one hand, and, on the other, broadens the issues to signify social phenonena as well but not at the expense of the individual experience» (Bertha Csilla, "Theatricality and Self-Reflexivity: The Play-within-the-Play in Select Contemporary Irish Plays", in Irish Theatre in Transition: From the Late Nineteenth to the Early Twenty-First Century, Donal Morse (dir.), New York, Palgrave Macmillan, 2015, p. 113).

44. À sa manière, The Secret Fall of Constance Wilde faisait écho à l'Irlande contemporaine, notamment au premier référendum sur le divorce, qui s'était soldé par un échec en 1986. Le divorce ne devint légal qu'après le second référendum (novembre 1995) suivi par l'adoption de la loi en juin 1996. Sur le plan sociétal, il convient de ne pas oublier les violences sur mineurs, évoquées dans la pièce, et qui firent l'objet d'une reprise plus manifeste dans Christ Deliver Us!, adaptation de la pièce de Frank Wedekind, L'éveil du printemps.

45. Thomas Kilroy, The Secret Fall of Constance Wilde, p. 68. 
(re)créateur, subtil écho de sa propre démarche. En effet, avant que le plateau ne s'obscurcisse de manière définitive, Constance donne à lire une vie avec l'autorité d'un interprète qui voit par-delà les apparences. En position de juge suprême, son décodage biographique d'Oscar s'adresse autant au spectateur qu'à ses enfants.

"[...] try to release the soul from his body, even when his body was still alive» introduit une dimension physiologique qui ne saurait être ignorée, puisqu'elle renvoie implicitement aux causes de son emprisonnement. L'essentiel, cependant, réside peut-être dans l'évocation d'un accomplissement impossible, qui inscrit la rupture au cœur de sa personnalité et trace le portrait d'un artiste marqué par une vision hors normes.

Sans équivaloir à la reconstruction d'un mythe, cette ultime caractérisation de Wilde incite à percevoir The Secret Fall of Constance Wilde comme la poursuite d'un dialogue entre les deux dramaturges, via un hommage rendu à un créateur. La manière dont Kilroy s'est approprié la commande de l'Abbey Theatre, en renversant quelques attendus thématiques et en explorant des esthétiques exotiques, pose plus largement qu'à l'origine la question de son statut auctorial. À cet égard, nous pouvons constater que des points de convergence apparaissent avec les auteurs que Foucault nomme des fondateurs de discursivité:

Ces auteurs ont ceci de particulier qu'ils ne sont pas seulement les auteurs de leurs œuvres, de leurs livres. Ils ont produit quelque chose de plus: la possibilité et la règle de formation d'autres textes. [...] Freud n'est pas simplement l'auteur de Traumdeutung ou du Mot d'esprit; Marx n'est pas simplement l'auteur du Manifeste ou du Capital: ils ont établi une possibilité indéfinie de discours ${ }^{46}$.

Au vu de la place singulière de The Secret Fall of Constance Wilde sur la scène irlandaise, cette pièce invite à poser un regard rétrospectif sur l'œuvre de Kilroy et son statut d'auteur. Agissant à l'origine comme un catalyseur d'idées sur la scène théâtrale irlandaise, il a, au fil du temps, marqué de son empreinte un univers théâtral qui s'est enrichi grâce à ses perspectives novatrices. Son rôle fondateur dans une nouvelle approche des adaptations, avec The Seagull, fait écho à ses créations dans The O'Neill, Tea and Sex and Shakespeare, Double Cross ou même Talbot's Box, pour ne citer que quelques pièces. Ses innovations dramaturgiques, qui sortent des cadres classiques, invitent à l'expérimentation en se nourrissant parfois d'autres cultures. C'est pourquoi, The Secret Fall of Constance Wilde, perçu non seulement sous l'angle de son état textuel définitif, mais aussi sous celui d'une œuvre en gestation, permet de mesurer que Kilroy n'est pas simplement un auteur dramatique, mais qu'en Irlande, selon la formule foucaldienne adaptée au monde du théâtre, il fut et restera un fondateur de théâtralités.

Thierry Dubost

Université de Caen Normandie

46. Michel Foucault, «Qu'est-ce qu'un auteur?», p. 832. 